\title{
Power Network of Penghulu Adat in The Concurrent Regional Election in West Sumatera
}

\author{
Asrinaldi
}

\begin{abstract}
This article describes the power network of Minangkabau's penghulu adat in West Sumatera. As known in West Sumatera, the penghulu has a strategic position in the Minangkabau community. Its position in traditional institutions is of utmost importance, especially in bridging the interests of the community in the political and governance processes in the nagari. This is deemed feasible as penghulu adat is capable of optimizing their power network and utilizing traditional institutions that they congregate in. In explaining the power network of penghulu, this study used a descriptive type of qualitative approach. Furthermore, this research found various types of formation in penghulu's power network which serves as the basis for their involvement in the political process of the village. Firstly, the establishment of penghulu power networking through personal capabilities recognized by the community in the village. Secondly, the establishment of penghulu power networking through traditional authority. Thirdly, the establishment of penghulu power networking which originates from the additional legitimacy of local governments, particularly for penghulu considered to represent the local government's interests in the village. Fourthly, the establishment of penghulu power networking based on the recognition of their peers by bestowing the title of sangsako in the tribe.
\end{abstract}

\section{Keywords:}

power; network; politics and penghulu adat.

\begin{abstract}
Abstrak
Artikel ini menjelaskan jaringan penghulu adat dalam masyarakat Minangkabau di Sumatera Barat. Sebagaimana diketahui, penghulu memiliki posisi yang sangat strategis dalam masyarakat Minangkabau. Bahkan posisinya dalam kelembagaan adat sangat penting, terutama menjembatani kepentingan masyarakat dalam proses politik dan pemerintahan di nagari. Hal ini dapat dilakukan karena penghulu dapat mengoptimalkan jaringan kekuasaan yang ada pada diri mereka dan kelembagaan adat tempat mereka berhimpun. Untuk menjelaskan jaringan kekuasaan penghulu ini, maka penelitian ini menggunakan pendekatan kualitatif deskriptif. Dari kajian ini ditemukan bahwa terdapat empat proses pembentukan jaringan kekuasaan penghulu adat yang menjadi dasar bagi mereka untuk terlibat dalam proses politik dalam Pilkada, khususnya di nagari tempat mereka berdomisili. Pertama, pembentukan jaringan kekuasaan melalui kemampuan personal penghulu yang memang diakui oleh komunitas di nagari. Kedua, pembentukan jaringan melalui otoritas tradisional karena garis keturunan. Ketiga, pembentukan jaringan kekuasaan karena adanya legitimasi tambahan dari pemerintah daerah, khususnya kepada penghulu adat yang dianggap dapat mewakili kepentingan pemerintah daerah di nagari. Keempat, pembentukan jaringan kekuasaan karena pengakuan rekan sejawat melalui pemberian gelar adat sangsako di dalam suku.
\end{abstract}

\footnotetext{
- Department of Political Science, Faculty of Social and Political Sciences, Andalas University

Email: asrinaldi4@yahoo.com
} 


\section{Kata kunci:}

jaringan; kekuasaan; politik dan penghulu adat.

\section{Introduction}

Traditional power in modern political activities constantly incites the attention of scientists. This is due to the extensiveness of power legitimacy in traditional society which is often abused by power holders and utilized for political interests. In the contemporary context, the use of traditional power is often linked to activities of General Election (Pemilihan Umum - Pemilu) or Regional Election (Pemilihan Kepala Daerah - Pilkada) by involving the masses (Sulistiyanto \& Erb, 2009). In Indonesia, the influence of traditional elites remains profound in the daily lives of the community. This becomes even more prevalent as the authority wielded by traditional elites in their communities tends to form a very strong bond of patronage subsequently viable to be used for political interests (Aspinall \& Sukmajati, 2016: 4-6). As an example, Aspinall \& Sukmajati emphasize that patronage strategy became the main option for every candidate running in the legislative election of 2014. They tended to use their informal networks through brokers in the constituencies to collect votes (2016: 5). The established relationship becomes a substantial part in the mobilization of power used for the political elite's interests. In line with this view, Sulistiyanto \& Erb (2009) also found patronage tendencies throughout the electoral democracy process in Indonesia. The number of political elites utilizing traditional power networks through patronage patterns as one of the means in mobilizing support during the regional elections were quite substantial (cf. Prasad, 2016: 23-24).

To the pluralists, power is not actually owned by a particular class, such as the state. Power, in its general limitation, is also owned by the community and even by individuals in the community who interact on behalf of the power vested in their selves. In order to achieve an understanding with other individuals in the community, power needs to be actualized into forms of strategies which will ultimately result in a mutual agreement among them (Foucault, 1982). This is also the case in the penghulu adat (customary chief) who acts on behalf of themselves and also on behalf of their status as local leaders of the cultural and customary institutions who assume certain roles and functions in the community.

In developing countries, traditional authorities represented by informal leaders indeed remain a necessity to the government. The involvement of informal leaders has strong connections to the limited capability of the government in encouraging community involvement in program implementation. Additionally, traditional communities are still bound with cultural value systems which can only be understood by the penghulu adat. Herein lies the government's difficulty in garnering public support, especially in implementing development programs. The government is fully aware that the influence these traditional leaders have remain relevant in the practice of modern democracy. Aside from having power in the community one leads, the penghulu adat also possess power networks which can be utilized for political interests. Nevertheless, the power of penghulu adat has actually undergone a transformation to becoming a part of modern power/authority. Particularly, in a number of cases, dominant power relations between the holder of traditional power and holder of modern power such as the government have been observed to occur.

The presence of penghulu adat and the power they wield have actually gained the attention of previous researchers. Graves (2010) and Hadler (2010) have explained the matter 
although not in the context of practical politics utilization such as the regional election. Graves, for instance, has thoroughly stressed evidence showing colonial administration politics taking advantage of penghulu adat influence for their own interests in the Minangkabau region. The colonial administration had significant interest in the legitimacy owned by penghulu in the Minangkabau community in order to control the community through the power of penghulu adat they recognize. This is why maintaining the status quo of penghulu who were proponents of the colonial government was a substantial strategy for the Dutch colonial administration in Minangkabau. In a number of activities in the nagari (village), the recognized penghulu was even appointed as the head of a territorial political unit known as kelarasan (2010:75-85). Kelarasan is a government system conducted in the customary administration of Minangkabau which consists of two forms of kelarasan namely bodi caniago and koto piliang. The position of laras head (lareh) entailed a salary provided by the colonial administration hence binding the penghulu adat as the head of the laras.

According to Hadler (2010), the Dutch colonial government took advantage of the nagari head (wali nagari) to force communities in the nagari to grow coffee plant and imposed coffee tax on the Minangkabau community. Additionally, "In the 1860s, a more recent position of penghulu suku rodi was introduced to manage both the collection of coffee and the implementation of slave labor duties" (2010: 56). Observing this term, the ethnic penghulu indirectly became entrenched in political and administrative activities, particularly in strengthening the position of the reigning government at the time.

Contemporary development reiterates that the power of traditional authority has currently experienced a transformation in its leadership role and has adapted to global influences such as democratization process occurring in many countries (Hughes, 2000).
This phenomenon can also be observed in the implementation of penghulu adat power in West Sumatera. Even the regional election which is an important process of democratic consolidation has altered the behavior of penghulu adat in political activities at the regional level as of current. The power politics of penghulu adat no longer exists merely in socio-cultural spheres, but it touches on dimensions of politics and administration (Asrinaldi, 2016: 31). Therefore, a more in-depth study on the shift in the utilization of penghulu adat's political power and power networks is imperative, particularly in the effort of reconstructing the influence of penghulu adat's power network in activities of modern politics.

This article strives to explain the tendency of power utilization by penghulu adat as individuals exerting their power and functions in customary institutions, mainly in the regional election activities. The argument to be established in this study is that there is a utilization of power networks by political elites to mobilize support in the concurrent regional election of 2015 by involving penghulu adat in nagari (villages) throughout the West Sumatera Province. These power networks were formed by utilizing existing traditional authority derived from the personal capacity of the penghulu adat. Hence, there are two problems that will be explained in this article, namely: how was the penghulu adat power networks established in the administrative and political activities of the West Sumatera Province; and, how did the utilization of these power networks work in and out of their ethnic group.

\section{Methods}

The analysis in this article is based on field study data by using a descriptive qualitative approach. This approach was purposely chosen to explain the phenomenon regarding the utilization of traditional power networks by penghulu adat during the concurrent regional election held in West Sumatera. The character 
of this descriptive qualitative research is to explain factual and realistic aspects in social, cultural and political activities of penghulu adat who tended to involve themselves in regional election activities due to them being involved by the regional head candidates or due to their own personal intent to be involved for particular goals.

The research data was gathered through in-depth interviews with sources that directly understand the subject matter such as interviews with regional head candidate involved in the concurrent regional election and the penghulu adat serving as a member of that candidate's campaign team. As much as 24 individuals were interviewed in this study as a basis to analyze the phenomenon. Some of the interview excerpts were included in the analysis section to strongly illustrate actual events occurring in the community. Data collection was conducted from the month of April until July of 2016 in several regions holding concurrent regional elections that are assumed to have been witness to intensive involvement of penghulu adat in places such as Solok Municipality, Dharmasraya Regency, Solok Regency, Tanah Datar Regency and West Sumatera Provincial level regional election. Additionally, the winning regional head candidates in these regions were also penghulu adat in their respective tribe and ethnic group. Therefore, the sociological background of the elected regional head candidate in the research area, who were also penghulu adat, undoubtedly influenced the formation of the penghulu power networks in their election. A triangulation process or data validity test was also employed in order to ascertain that the acquired data has valid reliability, that is by reviewing the relevance of concept and data sources obtained in the field. For triangulation of data sources, a number of interviews were also carried out with political party committees who were part of the regional head candidate campaign team.

\section{Discussion}

Upon examination of the patronage relation established between patron and client in the community, it is indicative that the said relation demonstrates the presence of a dominant power wielded by a few individuals over that of many. This dominance can be observed through the behavior of a majority in a region acting in accordance to the interests of the group assuming the role of patron. Conceptually, "Patron client relationship are legitimated by traditional conceptions of personalized power and a system of political deference embodied in religious and cultural values. Traditional patrimonial leaders supply security and protection that is remunerated by the followers' passive loyalty." (Deasy Simandjuntak, 2013: 99). It is not uncommon that this resource is utilized by the patron for the sake of their own political interest, or utilized by political elites having interest with the resources owned by the patron. For instance, in the local context of West Sumatera, the patronage relationship can be established from traditional authority owned by penghulu adat due to the network of power he wields.

The discussion in this section is elaborated into two parts, firstly, regarding the concept and utilization of penghulu adat power network in West Sumatera. A review of this concept is substantial in understanding the shift in the concept of penghulu adat power, which has been commonly known in the social life of nagari in West Sumatera, with the current practice of modern government. Subsequently, the construction of the concept of power through the formation of the penghulu adat power networks will be more easily identified. Secondly, the discussion regarding the formation of network and its utilization in the administrative and political processes. In the political context, the formation of the penghulu adat power network will be observed through the regional election process which involved them as well. 


\section{Power Network and Traditional Authority of Penghulu Adat}

Power network is the relation of dominant power prevailing in the community. The accumulation of power possessed by every individual tends to be used to accomplish a particular interest. Even more so in the political context, wherein the individual power is bound in the network that is purposively formed or that forms naturally. Foucault further elaborated that individuals play an active role in articulating the power that shapes them. Bearing in mind that power is the mechanism and strategy that regulates life to be more orderly and mutually habitable. Hence, it is necessary to have a mutually agreed upon set of rules called the normalization process for these power wielded by individuals to run well.

As an example, in the Minangkabau ethnic group the power of penghulu adat is not merely limited to social and cultural context. The power of the penghulu also permeates the administrative and political spheres, because penghulu in essence are also free individuals assuming the role of political subjects. Penghulu, in certain cases, can intervene the implementation of formal administration under the control of wali nagari who are directly elected by the community. This intervention in authority can undoubtedly be done due to the prevailing power network he possesses, that is as an individual bearing traditional authority and as an individual assuming the role of a rational political being. This is the form of active role penghulu adat possess in articulating the power they hold.

One of the source of power which became the basis of establishing the penghulu adat power network is their ownership over traditional authority. The concept of traditional authority has indeed caught the attention of scientists. This interest refers to the role of authority holder in a traditional community who tends to use power for political ends such as general elections. For instance, Tronvoll \& Hagmann
(2012:4-5) clarified the presence of traditional power influence on general election dynamics in Ethiopia. The fact of the matter is that both the government and the opposing party tended to use traditional authority to mobilize voters, particularly during general elections. The involvement of traditional authority elites even provided legitimacy to candidates suggested by political parties. This is meant to secure votes given by electorates bound under the traditional authoritative power for the suggested candidates during the general election. In other words, tradetional authority became one of the instruments utilized in conducting pre-selection of candidates before the start of general elections.

The position of the elites with their traditional authority is quite revered in communities that still adhere to clientelism culture. Particularly when general elections are held, the function of these traditional authority wielding elites is highly sought after by candidates-due to their strategic position in mobilizing supports. It is obvious from this trend that the elites bearing traditional authority are not mere remnants of the past, but they are elites assuming dynamic roles in bridging the past, present and future of a community (Tronvoll \& Hagmann, 2012: 5).

In general, the ongoing phenomenon in the context of controlling individual power within a traditional community is also a part of political patrimonialism. This patrimonialism is clearly a form of elite domination over the political system by utilizing their power, including utilizing traditional culture, religion and kinship network that are connected to social and cultural values. Furthermore, patrimonialism aims to create stability in the system of politics and government according to certain interests. The leaders produced from such patrimonial understanding tend to be dominating as they obtain legitimacy from their clients based on the traditional authority they possess (Vel, 2008). 
There are numerous studies looking into the influence of this primordialistic cultural relation on political activities. This culture of primordialism is even considered as the driving force in mobilization of the masses. This can happen because of the traditional leaders' dominance who have inherited power from a noble family, local elites or royal descendants. These noble group, local elites or royal descendants are commonly revered so that whatever their attitudes and views are, their followers will abide by them. This primordialism also restrengthens the patron-client relationship of communities in developing countries, particularly those living in the rural regions. It is often the case that their position is utilized to influence political decisions made by the community. Even the use of money or goods in general elections to mobilize support frequently occurs, as written by Wang (2014:14) that “...villagers' high participation rate can be due to either government mobilization (by paying money to villagers who vote) or by mobilization of village elite (by using the influence of personal relationships)."

In the Minangkabau community, the practice of patrimonialism can be observed from the position of penghulu adat in the nagari. The penghulu adat are usually the leaders of their tribes. As a leader, they are fully responsible not only to the nibling, but also in the use of the noble cultural legacy (Navis, 2015). The title of penghulu is generally inherited from generation to generation, but there are also other requirements which must be fulfilled in order to become a penghulu such as having righteous character, being intelligent and knowledgeable, honest, and fluent in speech (Idrus Hakimy, 2001: 7-10). This serves as the basis for penghulu to take actions that are subsequently followed and obeyed by the community he leads. The penghulu who has fulfilled these requirements would usually have strong legitimacy.

The influence of penghulu's traditional authority in the Minangkabau community has long been known by many experts. Graves (2010: 31 ), for instance, explained that the position of penghulu in the tribe or ethnic group is inherited based on the matrilineal lineage. The penghulu is responsible to his clan, including in preserving inheritance and relations with other clans in the nagari. As elaborated by Benda-Beckmann \& Benda-Beckmann (2013: 48) penghulu has "...the basic constituent units for economic and political organisation." Even so, this traditional authority of penghulu in West Sumatera is undergoing a shift due to the strong influence of modern power/authority. One of them being the strong interference of the government in conducting modern administrative functions to the lower level, namely in the nagari which consequently influences the power of penghulu adat. Nevertheless, under some conditions, the implementation of cultural and customary systems in each of the nagari is still given the attention they need so that the legitimacy of the nagari administrators are still maintained.

Actually, the study on the penghulu's traditional authority ownership has also been previously explained by Max Weber. In his book, The Theory of Social and Economic Organization (1947), Weber explained that the prevailing legitimacy in traditional authority will result in legitimacy from its followers because the said authority/power is derived from the belief in the sanctity of tradition which has been practiced for a long time in the community. The practiced tradition is believed to have the capacity to lead them to the desired objectives in life. The belief in traditional power originates from values the community have faith in and are practiced to become developing culture and customs. Through the actualization of cultural and customary values, a leader obtains legitimacy to lead the community.

The power legitimacy of penghulu adat in Minangkabau is generally derived from customs and culture that serve as a guide for the community. In the Minangkabau tradition, the penghulu are men who are descendants 
from the mother's ancestry (matrilineal). In the mother's lineage, he is the mother's brother who becomes the mamak (uncle) to the mother's children (Graves, 2007). This is why in the Minangkabau culture "the leadership of the tribe and group in the community belongs to the mamak. The definition of mamak is literally the mother's brother. Even sociologically speaking, all men of older generations are mamak" (Navis, 2015: 130). It is in the hands of the penghulu that all decisions relating to sako, pusako and activities of the children and nibling in the clan are considered. Indeed, at glance, it seems that penghulu has quite a substantial power in the Minangkabau ethnic group. However, the power wielded in the hands of penghulu certainly cannot be exerted to his heart's content. Particularly because in the penghulu's exercise of power, the philosophy of adat nan sabana adat (true custom/norm), that is "Adat Bersendikan Syarak, Syarak Bersendikan Kitabullah" (custom is based on sharia, whilst sharia is based on the Holy Quran), becomes the indisputable main guide to lead.

Although the power of penghulu adat is legitimized by values of custom and culture, in practice and its development the penghulu's power could also wax and wane. This is in line of what has been revealed by Irwan Prayitno Datuak Bandaro Basa - the penghulu of Tanjung Kenagarian Pauh IX clan, who is also the elected Governor of West Sumatera in the concurrent regional election. In his opinion "the rise in customary power is closely related to the network owned by a penghulu whether he uses customary power, personal relations and other social relations in the community." 2 Particularly when in his daily life, the penghulu has broad social and cultural relations in other tribes and clans in the nagari. This is in accordance to the essence of power as Foucault (1982) explained that power has a relational dimension between actors. Every

\footnotetext{
2 Interview conducted on June 25, 2015 at the governor's residence.
}

relation between the actors will produce power in real life. That would also be the case when we observe the power of penghulu adat wherein the power they possess is not only imbued in the penghulu's self but also in the relations that are established because of the power vested upon him. As an example is the power formed between the penghulu adat and the regional government. In order to understand their relationship, we must be aware that there is power which mutually influences and supports one another. But, specifically for penghulu adat, as long as that power/authority is used for the interest of their ethnic group and community with a righteous objective, the legitimacy of the penghulu's power will see an increase. On the contrary, the penghulu's power legitimacy will cease to be if it were merely used for his own self interest. As a result, the advice and opinion of the penghulu would no longer be heard by his community and tribe. In the most extreme cases, the penghulu would not be involved in the decision making process of consultation assembly held by his people. On the other hand, the nibling who are the penghulu's responsibility to begin with would no longer seek his advice and opinion, especially regarding issues or problems they encounter. ${ }^{3}$

In the modern context, the spread of penghulu adat's legitimacy to power in the Minangkabau customary life has also been influenced by its surrounding environment. Particularly with the advent of modernization which is signified by progress in knowledge and technology which impacted on the existence of penghulu adat. This means that mastery over knowledge and technology is also an inseparable part in strengthening penghulu adat's legitimacy to power in Minangkabau. It is often the case that a penghulu's power will rise in stature and influence if he were to possess high competency in knowledge. This is because the

\footnotetext{
3 Interview with Marlon Martua Datuak Rangkayo Mulie, campaign organizer for the elected regent/vice regent pairing of Dharmasraya, on July $3^{\text {rd }}, 2016$.
} 
social status of the penghulu in his community and clan would also gain more strength and significance (cf. Abdullah, T., 2009: 5-12). Contrarily, if the community he leads were to possess more advanced mastery of knowledge and technology than him, the presence of the penghulu's influence would indirectly be less substantial. This is the reality in the practice of penghulu adat's power. In line to this condition, Idrus Hakimy clarified that penghulu should possess "knowledge about the people he leads, harto pusako, about the korong kampong and origins as well as the negari [nagari]. Be knowledgeable about the sharia and customary law, and be capable of implementing them in resolving disputes occurring in the living surroundings of his people and negari"(2001: 26). Without all of the above, the existence of penghulu would merely be a symbolic one within the tribes and people of Minangkabau.

From another aspect, the existence of penghulu adat is also influenced by government policy, specifically following the issuance of Law No. 6 year 2014 on Village. Prior to this, the election system of wali nagari (village head) in West Sumatera had also been subject to change based on Law No. 32 year 2004 on Regional Government which was eventually followed by Governmental Regulation No. 72 year 2005 on Village. The wali nagari were no longer elected based on the primus inter pares principle because of their personal excellence being acknowledged by their community through a deliberation process but through community support in a direct election of wali nagari. The result of this direct election was that there were quite a lot of rivalries observed between the penghulu adat and ninik mamak to support wali nagari originating from their tribe or community. It was not seldom that even penghulu adat were tempted to participate in the wali nagari election because they are confident with the influence of their traditional authority that they consider influential due to the support of their nibling. These competitions frequently brought about tensions which shook the solidity of power network in the nagari.

Thus, it is clear that the existence of penghulu in the community is very dependent on the utilization of the power network they wield. This network of power emerges as a form of implementation from their function as penghulu which originates from traditional authority acknowledged by their community. Even in the context of modern life, this traditional legitimacy is still required by government and political institutions for short term political interests. For instance, to a regional head candidate, the utilization of power network owned by penghulu adat directly relates to their access to the nibling of that tribe and group, particularly in the nagari. We can imagine the amount of support which can be acquired by a regional head candidate from the nibling of a penghulu adat in a nagari. Particularly if the mobilization of support carried out by the penghulu adat received full response from his nibling. Because of this, the traditional legitimacy possessed by penghulu adat often became the key to a regional head candidate's success in winning the regional election. Thus is also the case in the implementation of administrative functions, the assistance of penghulu adat becomes necessary to carry out the functions of political institutions and governments in the West Sumatera area.

\section{The Formation of Penghulu Adat Power Network}

One of the strength penghulu adat wield is their network. The penghulu's power network is formed in their traditional community which concurrently affords them the legitimacy to take actions. Additionally, this network is also formed due to their informal relations to government authority/power. The power of penghulu adat in West Sumatera is a substantial necessity, particularly in assisting to resolve problems encountered by government administrators. Cases of nibling disputes 
among nagari which is rooted in horizontal conflicts are commonly resolved through customary means involving the penghulu. As an example, the conflict of land boundary dispute between Nagari Muaro Pingai and Nagari Saning Baka in the Solok Regency which was leading to a riot was resolved through customary means by involving penghulu adat of the respective nagari and facilitated by the regent and local police force. ${ }^{4}$

Another example is the conflict between the people of nagari and the security apparatus regarding the case of illegal mining in Sijunjung Regency, South Solok Regency and Dharmasraya Regency which was also resolved through the involvement of penghulu adat. The mediation undertaken by the penghulu adat with the security force was successful due to the Head of Indonesian Police Regulation No. 32015 on Community Policing. In this case, the penghulu adat who also acted as the leader of the clan from the nibling who were in dispute strived to resolve the problem through negotiations with the police so it does not become a legal issue. The resolution process went smoothly in avoiding a more intense conflict between the nagari community and the local police. ${ }^{5}$

It is interesting to note that the existence of penghulu adat will in fact gain more significance due to the power network they wield. Hence, these power networks will serve as social and political capital for the penghulu in carrying out their cultural and customary functions as well as in fulfilling their own personal interests. It can subsequently be understood that these power networks were formed due to the personal capacity of penghulu adat. Their personal capacity is closely related to the resources they have such as the knowledge

\footnotetext{
4 https://issuu.com/haluan/docs/hln280113/4, accessed on October 11, 2016.

${ }^{5}$ http://harianhaluan.com/news/detail/44528/tambangemas-ilegal-di-sumbar-ibarat-bom-waktu-, accessed on October 11, 2016.
}

and wealth they own. It is often the case that a penghulu with such network will obtain a noble stature among the life of his tribe and people. ${ }^{6}$

Additionally, penghulu adat also serve as mamak that the nibling depend on, specifically, in the economic aspect. This results in the difficulty of nibling to refuse the penghulu's wish and refuse their request for support. This patron-client relationship frequently occurs and tends to be used for political interests. For example, in the context of regional election, the opinion of the winning penghulu who indeed does have authority in customary matters, knowledge, and economic resource tends to be heard. Their nibling won't even hesitate to ask which candidate they support in the general election (Pemilu) or regional election (Pilkada) held in the nagari. This is in line with the Minangkabau custom of kamanakan saparintah mamak (the nibling obeys the uncle). There were usually a lot of opportunities in which the penghulu adat disseminated support regarding the regional head candidate they choose to their nibling or to community figures in the nagari. These actions the penghulu took is in accordance to their function illustrated in the philosophy of pai tampek batanyo, pulang tampek babarito (when you leave you (for his advice), when you return you report (recent news and information)). On the contrary, if the penghulu adat did not have resources such as sufficient knowledge or control over customary land, the nibling would usually pay little attention to the penghulu adat's demands. There is, instead, a tendency for the penghulu's demands and actions to be criticized and evaluated by the nibling if it were deemed unsuitable to their interests. ${ }^{7}$

Secondly, the formation of penghulu adat power network is a result of the traditional legitimacy they maintain. As already known, the penghulu adat are leaders of clans and tribes

\footnotetext{
${ }^{6}$ Interview with Syamsu Rahim, Solok Regent for the 2010-2015 period in Padang on June $23^{\text {rd }}, 2016$.

7 Interview with H. Rusli Khatib Sulaiman Head of the LKAAM Solok Municipality on April the $5^{\text {th }}, 2016$.
} 
in a nagari. There are usually four or more clans with its respective penghulu adat in a negari. The interactions among the penghulu adat can strengthen the power network owned by a penghulu adat. It is in this context that power network becomes strengthened even further. The extent of kinship in each clan of the nagari has its own advantages for the penghulu adat for mobilization purposes on behalf of his clan's interests. The penghulu adat power network is seen as a means to strengthen the basis of political support in the general and regional elections (cf. Aspinall \& Sukmajati, 2016).

In fact, the mutual influence of power networks among penghulu adat also takes place in the nagari. Emotional proximity among penghulu adat in the nagari is also utilized to mutually support the interests of each penghulu. The relational pattern happening among them is indeed not claimed to be done on behalf of their respective clan and people. But, it is more of a closeness as peers in the nagari who jointly manage customs and culture in the nagari. The similarity in roles undertaken as penghulu adat and even similarity of interest in the nagari are the fundamental background in the formation of mutual collaboration among them. In reality, the pattern used by a penghulu adat in mobilizing the nibling will easily become a model for other penghulu adat to garner the same support from their own nibling. This is the impact of the ongoing interaction in the penghulu adat community found in the nagari.

The tendency to replicate is nothing new in traditional communities. The general idea is that the ethnic groups mutually adapt and adopt values, customs or behavior that are applied in their everyday lives. This is in line with Cohen's elaboration in his book Custom and Politics in Urban Africa:

"In the one case an ethnic group adjusts to the new social realities by adopting customs which are shared with other groups. In the second case an ethnic group adjusts to the new realities by reorganizing its own traditional customs, or by developing new customs under traditional symbols, often using traditional norms and ideologies to enhance its distinctiveness within contemporary situation." (2004: 1)

In the highly dynamic customary community of nagari, the change in norms and values tends to occur, particularly in political activities they participate in. Along with the involvement of their penghulu in practical politics, this more or less has an influence in their perspective on the political reality currently occurring in the nagari. The existing government policies strengthen the political role of the people up till the village level through the election of village head or election of wali nagari in West Sumatera based on Law No.6 year 2014 on Village, and this has changed their past views and habits which seemed to have distanced themselves from political activities.

Particularly, the strengthening of the community's politics through the implementation of decentralization, political decentralization to be exact, is capable of providing space for the community to be involved in every available political activity. Even political parties are becoming more intense in broadening their political networks to the village or nagari level. This phenomenon extremely differs from the New Order policy which had indeed restrained political activities undertaken by the party up to the village level. This, however, was not applicable to the Golkar party which was the party in support of the New Order regime. The village head at the time was even a major actor in mobilizing the masses affiliated to Golkar (Jones, 2010: 345). Government policies in the political aspect are indirectly stipulated in the Village Law and the Regional Government Law which aims at raising political awareness of the community 
as a prerequisite to quality local democratic life. Over the last three years, even political dynamics at the lowest level, such as the nagari in West Sumatera, have been undergoing rapid progress and development. This can be observed in their enthusiasm in following the extremely dynamic wali nagari (village head) election. In the practice of the wali nagari election, all attributes of power and traditional authority were employed to bring certain candidates to victory. While previously, attributes of the clan/ tribe's traditional power/authority were only used to strengthen customary and cultural values within the confinement of the nagari area. Ever since the direct election of regional head had been carried out, its influence can be directly observed through the strengthening of the clan's political identity in various regions.

Thirdly, the formation of penghulu power network took place due to additional acknowledgement from the regional government to the position of penghulu who are considered to be capable of assisting the government. Although the appointment of penghulu adat falls under the mandate of the customary community, in a number of issues the influence of regional government in providing additional "legitimacy" to the penghulu is no less significant. The presence of penghulu adat, especially those that are recognized to be capable in assisting the implementation of government programs in the nagari will become a matter of importance to the regional administration. Upon observation of this reality, the regional government has indirectly provided recognition to the penghulu adat that are appointed by their tribe and clan in the nagari. Surely, the government's acknowledgement will also ease the penghulu adat in carrying out their functions among their tribes and people. ${ }^{8}$ Particularly when the position of the penghulu is linked to the

\footnotetext{
8 Interview with Zul Elfian Datuak Tianso, elected Mayor of Solok in the 2015 concurrent regional election, on June $29^{\text {th }}, 2016$.
}

implementation of development programs in the nagari which are included in the regional government's programs and activities. It is often the case that the assistance given to the nagari administration also involves the consideration of the penghulu adat in the nagari. Even the political lobbying undertaken by the penghulu becomes a substantial part of the political process in order to obtain assistance from the head of the region.

The close relationship between the penghulu adat and regional government is nothing new in the political context of Minangkabau. In the ethnical history of Minangkabau, the relationship between the penghulu adat and colonial authority had already been established, particularly to mutually maintain their respective interest. The Dutch colonial government did indeed utilize the influence of penghulu adat to strengthen their position in the nagari (Graves, 2010). Conversely, the relationship established with the Dutch colonial government was also utilized by the penghulu adat to broaden their influence in the community's activities.

During the colonial era, the penghulu of the nagari were chosen and selected by the colonial government to be appointed as spokespersons for the Dutch to the community in the nagari as well as to collect taxes from them. They are called the head penghulu by the Dutch with the main objective of assisting in the interest of the colonial administration. The appointment was aimed at facilitating the Dutch colonial interests in the nagari in implementing slave labor of planting coffee. Even so, the acknowledgement given by the Dutch colonial government also impacted the social mobility of the penghulu adat which consequently increased their access to wealth and power (Biezefeld, 2007: 209; also see Hadler, 2010: 56-57). Thus, the additional legitimacy provided to the penghulu had taken place for a long time with particular purposes.

This phenomenon can be compared to the current period, wherein the regional 
government also provides recognition to the penghulu adat. As an example, the government's acknowledgement to the penghulu adat is given by appointing them as public officials in the scope of regional administration. It is often the case that the penghulu adat also work as State Civil Apparatus (Aparat Sipil Negara - ASN) and their position as ASN can be utilized by the regional head to support development programs in the regions. For example, by appointing them as echelon officials in the regional government, the regional head can indirectly intervene in the implementation of the penghulu adat's functions. As for the penghulu adat also serving as ASN, the acknowledgement to their authority will increasingly strengthen their position in the community. Particularly because the current development in the life of the people and of the nation following Indonesia's independence has reduced the power and authority of traditional figures seeking for alternative legitimacy, especially from the state.

"After independence local leaders whose authority had become partly based on positions provided by the national state had to find new ways to connect to the national centre. Traditional leadership is no longer sufficient to remain in power locally." (Vel, 2008: 8)

This is why it is no surprise that penghulu adat serving as ASN intend to be politically affiliated during general or regional elections as a shortcut to accomplish their goal of obtaining legitimacy and restrengthening power and authority in their tribes and community. Although there are not many of them, ASN officials with a background as penghulu adat did indeed furtively involve themselves in regional elections by providing support to the regional head candidate that serves as their patron. Nevertheless, the support given by the ASN officials who were also penghulu adat was not too significant due to the limitation of political wiggle room they have as stipulated by the restriction for ASN to engage in politics (Asrinaldi, 2016:61-65).

Fourthly, the formation of penghulu adat power network can also be understood from the environment of colleagues or peers they interact in. In the nagari, there are individuals possessing greater capabilities than other figures which leads to them being looked up as role models in social and cultural activities of the nagari. By having greater capacity, a person can even be appointed as penghulu even though he does not have direct lineage with the head of the penghulu adat. In this context, the title of penghulu adat can be given to someone who is considered to have contributed to developing the customs and culture of a tribe and community thus affording him with the title sangsako. The title of sangsako is indeed different to the title of sako which indicates direct lineage to the Minangkabau ethnic group. According to Idrus Hakimy (2001: 31), the title of sangsako is "a title of nobility given by the joint assembly through a consensus, and it is not inheritable as the sako title is." This means that this title can be removed based on the joint decision of the council of elders in accordance to customs if a person were no longer considered worthy of bearing the title as it is said in the traditional philosophy that sangsako pakai-mamakai, manuruik barieh balabeh. However, there is one concern regarding the matter, a penghulu with the title of sangsako has no relations whatsoever with the noble cultural legacy (pusako tinggi) which is the responsibility carried by penghulu afforded the title sako.

Even so, the involvement of penghulu adat with the title of sangsako tends to be carried out in order to successfully implement development programs in the government agenda. It is often the case that those given the title of sangsako are government officials considered to have assisted in the development of the nagari that afforded the title in the first place. Additionally, the title of sangsako is also 
given to political leaders who participated in assisting and developing the Minangkabau custom and culture which consequently reserves them the honor to be afforded this title.

The formation of power networks through their peers also has an influence on the political activities in the tribes and communities. Particularly when the person given the title of sangsako is a public official or a political figure. The procession of bestowing the sangsako title is only carried out among penghulu adat of the tribes and communities. This means that the assembly held to reach a consensus on behalf of nibling is represented to the penghulu adat of tribes and communities in the nagari. That is why, in relation to the general and regional elections, the support expected by a person appointed as a penghulu adat with the title sangsako tends to be carried out among peers of penghulu adat who appointed the penghulu with the sangsako title. The reason for this being that the penghulu adat with the title of sangsako do not truly have direct access to nibling or communities in the nagari.

Upon observation of the above phenomenon, it is clear that the power network of penghulu adat who have direct access to mobilize nibling are those that have networks deriving from traditional authority; they have the personal capacity of penghulu adat; and their traditional existence is acknowledged by the regional government. Meanwhile, the power network derived from a peer of penghulu adat has very weak influence in the nagari community. Nevertheless, those who bear the title of sasangko afforded by their penghulu adat peers still hold substantial position, especially in strengthening the position of the nagari in the administrative and political processes. There are quite a number of them with the customary title of sasangko who wield influence in the political, economic, and social fields. The nagari community usually takes advantage of the position of the figure they had afforded the sangsako title to help them develop the nagari.
In a number of issues, the customary title of sasangko given to figures regarded to have contributed to the Minangkabau tribes and communities can indeed provide positive impact to the nagari in the form of assistance or protection. It is interesting to note that when the person given the title sangsako by the nagari run as a candidate in the general or regional elections, assistance from the penghulu adat will subsequently come, including mobilization of electoral support from the community in the nagari with the purpose of bringing the said candidate to victory. This exchange of resources is obviously a part of the unavoidable political patronage in the context of contemporary politics in the nagari. This is in line to what has been clarified by Hanif (2009: 330).
"A relationship signified with the provision of political and economic resources from the patron who usually wields personal power/ authority to the beneficiaries of 'charity' who provide their loyalty and political support."

Upon observation of factual occurrences in numerous nagari in West Sumatera, the formation of penghulu adat power networks through traditional authority is not substantially supported by the personal capacity of the penghulu adat. As a result, the authoritative function of the customary leaders which should be implemented in the nagari becomes degraded. This is undoubtedly an issue for penghulu adat in carrying out their customary functions in the face of their nibling. Particularly because the ongoing modernization process also brings about progress in knowledge and technology which more or less has an impact on the nibling's point of views regarding the penghulu adat's traditional authority in the nagari. In general, the penghulu adat in Minangkabau remain dependant on traditional authority that is inherited through their lineage. Meanwhile, another source of legitimacy is also 
Table 1.

Formation of Penghulu Adat Power Network and Its Implications

\begin{tabular}{|c|c|c|}
\hline Formation Process & Relations with the Community & Power Implications \\
\hline Personal capacity & $\begin{array}{l}\text { Bearing direct influence on the nagari } \\
\text { community as their personal capacity is } \\
\text { needed by the nagari community. }\end{array}$ & $\begin{array}{l}\text { Mobilization process for political power is } \\
\text { viable as the penghulu adat has strong influence } \\
\text { in the community. }\end{array}$ \\
\hline Traditional authority & $\begin{array}{l}\text { Bearing influence on the community as } \\
\text { the lineage of the penghulu with traditional } \\
\text { authority is very strong in the tribe and } \\
\text { community. }\end{array}$ & $\begin{array}{l}\text { Mobilization of power is very dependent } \\
\text { on the personal authority and capacity of } \\
\text { the penghulu adat in the eyes of the nibling, } \\
\text { particularly those with higher education level. }\end{array}$ \\
\hline $\begin{array}{l}\text { Strengthening of } \\
\text { regional government } \\
\text { legitimacy }\end{array}$ & $\begin{array}{l}\text { Bearing quite a strong influence on the } \\
\text { community as acknowledgement of the } \\
\text { penghulu-ship is also given by the regional } \\
\text { government, particularly in assisting the tasks } \\
\text { of the regional government. }\end{array}$ & $\begin{array}{l}\text { A strong access to the regional government } \\
\text { will ease the mobilization of support from } \\
\text { nibling and the tribe so it tends to be utilized } \\
\text { for the interest of administrative and political } \\
\text { activities, especially during period of general } \\
\text { and regional elections. }\end{array}$ \\
\hline $\begin{array}{l}\text { Appointment by peers } \\
\text { of penghulu adat }\end{array}$ & $\begin{array}{l}\text { Bearing weak influence on the community. } \\
\text { The influence of penghulu whose power } \\
\text { network is formed through this process tends } \\
\text { to utilize the penghulu network appointed } \\
\text { through traditional authority because the } \\
\text { people bestowing the customary title of } \\
\text { sasangko are their peers in the traditional } \\
\text { penghulu adat. }\end{array}$ & $\begin{array}{l}\text { Direct access is in fact in the power of } \\
\text { the penghulu adat with basis of traditional } \\
\text { authority. This network tends to be utilized for } \\
\text { administrative and political interests. }\end{array}$ \\
\hline
\end{tabular}

Source: Primary Data, 2016

necessary in order to strengthen this traditional authority, namely knowledge and technology which are in fact developing in the lives of their nibling. This is one of the reason why the influence of traditional authority in the life of the nagari community begins to decrease along with the constant progress of modernization.

Additionally, the power network phenomenon prevalent in the Minangkabau ethnic group is also strengthened by influences from outside of their tribe and community. This can be seen in the historical relationship of penghulu adat with the Dutch colony which instead strengthened the position of penghulu adat in carrying out their customary functions and the function of the colonial administration (Graves, 2010). Meanwhile, in the current modern context, the position of the penghulu adat is also very much determined by the acknowledgement of the regional government, especially in assisting the implementation of the administrative function in the region their tribes and community reside in. usually the penghulu adat that are recognized will constantly be asked for their input, opinion and assistance in order to implement government programs. Even in the political context, as explained above, the influence of penghulu adat is also necessary to gain support from their nibling in the tribe and community.

Lately within the constellation of customary politics in West Sumatera, there is a tendency of bestowing the customary title of sangsako to individuals or figures considered to have contributed to the life of a tribe or clan in Minangkabau. Although the bestowing of this title of sangsako also adheres to the traditional ceremony attended by nibling of the tribe and clan providing it, there is little to almost no direct influence exerted upon the nibling. This honorary customary title is merely a political symbolization of a tribe and clan so that their existence remains acknowledged outside their own community. Thus, the influence of penghulu with the title sasangko is very low, particularly if the power network they form is used to mobilize support to their nibling in the nagari.

\section{Conclusion}


The role and function of penghulu adat in the nagari community have undeniably undergone a significant shift. Penghulu are no longer exercising their cultural and customary functions in the tribe and community. Penghulu adat have gone further and have begun to be involved in practical politics although it is still being done discreetly. This is the case at hand because there are still many nibling who are unhappy with the involvement of penghulu adat in activities of practical politics. Particularly if this involvement is linked to private and familial interests of the penghulu adat. Nevertheless, the involvement of penghulu adat in practical politics has become a necessity, even more so since the issuance of Law on Village, wherein the administrative activities at this lowest level of government are also steeped in practical politics activities. As an example, the political agenda in the nagari regarding the direct election of wali nagari has in fact involved the penghulu adat. Even political contestation involving the nibbling in the nagari is conducted openly so that political rivalries can be easily observed.

It is often the case that this rivalry bears an impact on horizontal tension in the community which also effects the psychological relations between penghulu adat and their nibling in the nagari. The direct election of wali nagari process is already an inseparable part of political life in the nagari today. This is why it is no surprise that there are rivalries among penghulu adat in obtaining the position of wali nagari. These rivalries could become more intense, particularly if each penghulu adat utilizes the power network they wield. Almost every penghulu adat strive to form their power network in order to accomplish their intentions.

Based on the four processes of power network formation elaborated in the above passages, the penghulu adat possessing traditional authority and supported by personal capacity is the one who will usually win the contestation. This phenomenon is a consequence of direct access to nibling who are their supporters in the running for the general and regional elections taking place in the nagari. In reality, there are a lot of regional heads utilizing the power networks of penghulu adat for their interest in winning the regional election. Penghulu adat are appointed as part of the campaign team or as volunteers managing field operations to mobilize the nibling's support.

Meanwhile, the utilization of power networks owned by penghulu adat who also gained recognition from the government due to their good personal character is given legitimacy by the regional government. These penghulu adat are usually appointed as regional government officials so they can assist to ease the implementation of regional government's development programs in the nagari where the penghulu adat resides in. Thus is also the case with the bestowing of the sasangko title to an individual which tends to be used for the sake of government program implementation. It is usually to exercise the development function in the nagari so that the implementation of the program can run smoothly, wherein the penghulu adat tends to be the facilitator in disseminating information regarding the development program. Particularly in certain aspects, the regional government can intervene by utilizing the position of the penghulu adat who is also an ASN legally bound to remain loyal to the superior.

For that reason, the power network wielded by the penghulu adat becomes a means utilized in mobilizing support within a tribe or community in West Sumatera. Although in practice, there are certain conditions required of the penghulu adat in order for the mobilization to be carried out according to the penghulu adat's interests. If these conditions are not met, it will be a bit difficult for penghulu adat to mobilize their nibling, particularly in activities of practical politics such as the general election or regional election. 


\section{References}

Abdullah, T. (2009). Indonesia Towards Democracy. Singapore: ISEAS Publishing.

Aspinall, E., \& Sukmajati, M. (2016). Electoral Dynamics in Indonesia: Money Politics, Patronage and Clientelism at the Grassroots. In E. Aspinall \& M. Sukmajati (Eds.), Patronage and Clientelism in Indonesia Election Politics (pp. 1-38). Singapore: NUS Press.

Asrinaldi. (2016). Masalah Keterlibatan Aparatus Sipil Negara dalam Pilkada, Analisis CSIS, 45(1):58-76.

Asrinaldi. (2016). Politik Kekuasaan Penghulu Adat dan Implikasinya Pada Kualitas Demokrasi Lokal di Sumatera Barat. Padang: LPPM Universitas Andalas.

Biezefeld, R. (2007). The Many Roles of Adat in West Sumatra. In Jamie S. Davidson \& David Henley (Eds.), The Revival of Tradition in Indonesian Politics: The Deployment of Adat from Colonialism to Indigenism (pp. 203-223). New York: Routledge.

Cohen, A. (2004). Customs and Politics in Urban Africa: A Study of Hausa Migrants in Yoruba Towns. Oxon: Routledge.

Foucault, M. (1982). The Subject and Power. Critical Inquiry, 8(4), pp. 777-795.

Graves, Elizabeth E. (2010). The Minangkabau Response to Dutch Colonial Rule in the Nineteenth Century. Singapore: Equinox Publishing.

Hadler, J. (2010). Sengketa Tiada Putus: Matriakat, Reformisme Islam, dan Kolonialisme di Minangkabau. Jakarta: Freedom Institut.

Hakimy, I. (2008). Pegangan Penghulu, Bundo Kanduang, dan Pidato Alua Pasambahan Adat di Minangkabau. Bandung: Remaja Rosdakarya.

Hanif, H. (2009). Politik Klientelisme dan Dilema Demokratisasi di Indonesia. Jurnal Ilmu Sosial dan Ilmu Politik, 12(3), 327-351.
Hughes, D. (2000). Pengaruh Timbal balik Peran Kepemimpinan Tradisional dan Demokrasi di Ponape. In Frank McLynn dan Arthur Tuden (Eds.). Pendekatan Antropologi Pada Perilaku Politik (pp. 382403). Jakarta: UI Press.

Jones, S. (2010). The Normalization of Local Politics? Watching the Presidential Elections in Morotai, North Maluku. In Edward Aspinall \& Marcus Mietzner (Eds.), Problems on Democratisation in Indonesia: Elections, Institutions and Society (pp. 330-348). Singapore: ISEAS Publishing.

Navis, A. A. (2015). Alam Takambang Jadi Guru: Adat dan Kebudayaan Minangkabau. Padang: Grafika Jaya Sumbar.

Prasad, K. (2016). Identity Politics and Elections in Malaysia and Indonesia: Ethic Engineering in Borneo. Oxon: Routledge.

Simandjuntak, D. (2013). Beyond Wealth and Pleasant Posture: Exploring Elite Competition in the Patronage Democracy of Indonesia. In J. Abbink \& T. Salverda (Eds.), The Anthropology of Elites: Power, Culture, and the Complexities of Distinction (pp. 95-112). New York: Palgrave Macmillan.

Sulistiyanto, P., \& Erb, M. (2009). Indonesia and Quest for "Democracy". In M. Erb \& P. Sulistiyanto (Eds.), Deepening Democracy in Indonesia: Direct Elections for Local Leaders (Pilkada) (pp. 1-37). Singapore: ISEAS.

Tronvoll, K., \& Hagmann, T. (2012). Introduction: Traditional Authorities and Multi-Party Elections in Ethiopia. In K. Tronvoll \& T. Hagmann (Eds.), Contested Power in Ethiopia: Traditional Auhorities And Multi-party Elections (pp. 1-30). Leiden: Koninklijke Brill, NV.

Vel, Jacqueline A.C. (2008). Uma Politics: An Ethnography of Democratization in West Sumba, Indonesia, 1986-2006. Leiden: KITLV Press. 
Von Benda-Beckmann, F. \& Von BendaBeckman, K. (2013). Political and legal Transformations of An Indonesian Polity: The Nagari from Colonisation to Decentralisation. Cambridge: Cambridge University Press.
Wang, G. (2014). Tamed Village "Democracy": Elections Governance and Clientelism in Contemporary Chinese Village. London: Springer-Verlag.

Weber, M. (1947). The Theory of Social and Economic Organization. Glencoe, Illinois: The Free Press. 